$\Longrightarrow$ Proceedings of the Second Annual Forestry Symposium 1996: Management and Sustainable Utilization of Forest Resources, Sri Lanka, 6-7 December 1996. (Eds. Amarasekera, H S, Ranasinghe, D M S HK and Finlayson, $W$. Published by Department of Forestry and Environmental Science, University of Sri Jayewardenepura, Sri Lanka (1998)

\title{
Hypsipyla SHOOT BORERS IN MELIACEAE: CURRENT STATUS
}

\author{
Jayanthi P. Edirisinghe \\ Department of Zoology, University of Peradeniya
}

\begin{abstract}
A brief of an international meeting held in Kandy in August 1996 to discuss the present situation with regard to this insects. It is suggested that the relatively low level of attack in Siri Lanka may he due to good overhead shade were the trees have been planted.
\end{abstract}

\section{Introduction}

The first international workshop on Hypsipyla shoot borers in Meliaceae was held in Kandy in August 1996, with 18 countrics participating. The objective was to assess the work done in the recent past on Hypsipyla shoot borers and discuss future priorities. This paper highlights some of the aspects that were discussed.

The fanily Meliaceac occurs throughout the tropics and includes many of the world's finest cabinet timbers. such as Swietenia (mahogany), Khava (African mahogany), Toona and ('edrela ("cedars"). They occur naturally or are planted in some 25-30 countrics. Two Hypsipyla species, H. grandella (Zeller) and H. robusta (Moore), are the most important pests of the Meliaceae. They have a distinct distribution. with $/ 1$. grandella confined to the New World and II. rohusta to Africa. Asia. Australia, and the Pacific islands. Table 1 lists the species grown in the countries that participated at the workshop, and also shows the distribution of the two /ypsypila species. Siwietenia macrophylla is grown extcnsively throughout the tropics. while Khava spp. are to be found mostly in Africa and Asia. Toona spp. in Australia, and Cedrela spp. in tropical America.

\section{Taxonomy of Hypsipyla}

Hypsipyla (Lepidioptera. Pyralidae) is a genus of moths belonging to the subfamily Phycitinae. Eleven species have been recognized; four from the New World and seven from the Old. Hypsipyla robusta was first described from Sri Lanka by Moorc in 1886. It had been collected from the fruits of the mangrove species, Xylocarpus granatum. Hypsipylla grandella was first described from Brazil by Zeller in 1888. The wide distribution of $H$. robusta (unlike that of $H$. grandella) in many continents and zoogeographical regions of the world suggests that this species may comprise many subspecies. The taxonomic revision of H. robusta is considered to be of great importance. It should involve an examination of the 
Edirisinghe

type specimen at the Natural Histony Museum. London. a study of the fit of the male and female genitalia, rearing from different native hosts, and the use of molecular techniques.

Table 1 : Participating countries, Mcliaceae grown, species of Hypsipyila

\begin{tabular}{|c|c|c|}
\hline Country & Meliaceac grown & $\begin{array}{l}\text { Hypsipvla } \\
\text { species }\end{array}$ \\
\hline Australia & $\begin{array}{l}\text { Toona anstralis, T. ciliata, } \\
\text { T. sinensis, Cedrela odorata, Melia azadirachta }\end{array}$ & H. robusta \\
\hline Bangladesh & $\begin{array}{l}\text { Swietenia macrophylla, } \\
\text { C. tabularis, S. mahagoni, } \\
\text { T. ciliata }\end{array}$ & H. robusta \\
\hline Brazil & $\begin{array}{l}\text { S. macrophylla, C. odorata, } \\
\text { S. senegalensis }\end{array}$ & H. grandella \\
\hline Costa Rica & C. extorata, S macrophylla & H. grandella \\
\hline Cubst & $\begin{array}{l}\text { (. adorata, S. macrophylla, } \\
\text { S. mahagoni, Khava sp., } \\
\text { T. ciliata }\end{array}$ & H. grandella \\
\hline Chawa & Khoraspp. & H. robusta \\
\hline I londuras & S. hunilis, C. odorata & H. gratidella \\
\hline India & $\begin{array}{l}\text { S. macrophylla, S. malagoni, } \\
\text { T. ciliata }\end{array}$ & H. robusta \\
\hline Indonesia & S. macrophylla, S. mahagoni & H. robusta \\
\hline Lans & $\begin{array}{l}\text { C. tahularis, } M \text { azadiracha, } \\
\text { S. macrophylla }\end{array}$ & H. robusta \\
\hline Maliaysia & $\begin{array}{l}\text { S. macrophylla, S. mahagoni, } \\
\text { K. senegalensis, K. ivorensis }\end{array}$ & H. robusta \\
\hline P'apula New Guinea & T. ciliata, T. anstralis, T. sureni & 11. robusta \\
\hline Philippines & $\begin{array}{l}\text { S. macrophylla, M. dubia, } \\
\text { T. calantas }\end{array}$ & H. robusta \\
\hline Solomon Islands & S. macrophylla. C. odorata & H. rohusta \\
\hline Sri Lanka & S. macrophylla, K. senegalensis & H. robusta \\
\hline Thailand & $\begin{array}{l}\text { S. macrophylla, S. mahagoni, } \\
\text { T. ciliata, T. sureni }\end{array}$ & H. robusta \\
\hline Vietnam & $\begin{array}{l}\text { (. tabulanis, K. senegalensis, } \\
\text { S. macrophylla, T. sureni }\end{array}$ & 17. robusta \\
\hline
\end{tabular}




\section{Biology}

The biology of Hypsipyla species has been described by several workers, most extcnsively by Beeson (1941). Information on the life-cycle stages, their duration, larval development and behaviour is well known. The females lay about 200-450 eggs during a period of 4-6 days, singly or in small clumps. Young larvae first feed on the epidermis of the host plant. and eventually burrow down the stem. They often abandon stunted or unsuitable stems and move to fresh ones to complete their development. There are four or five larval instars, depending on the nutrition of the lanvae. Pupation takes place in the upper end of the galleries made by the larvac. In warm weather, development from egg to adult is generally completed in 7-8 weeks.

Although the general biology of Hypsipyla is well known it was felt that certain aspects required clarification and further work. Those suggested at the workshop were

- nature of adult movement

- host plant selection

- population dynamics in relation to larval stages

- environmental influence on mating and oviposition

\section{Damage}

Damage results from the tumnelling of larvae in young terminal shoots, leading to the death of these shoots. Lateral shoots take over, ultimately producing stunted, continuously branching trees, of greatly reduced timber value. Even though the attacks rarely kill trees, economic losses can be considerable. In India, large scale reforestation with Toona spp. was abandoned because of attacks by $H$. robusta (Rao \& Bennet, 1969). Damage is known to be heavy during the first $3-5$ years; a maximum shoot infestation of $62.5 \%$ was reported from India in Toona trecs when they were $2-4 \mathrm{~m}$ in height.

The effect of shade received a great deal of attention at the workshop. Several authors, in presenting their country reports, stated that shoot-borer attack is reduced when trees are grown under partially shaded conditions. The effect of shade on damage therefore emerged as an important factor needing further study. The behaviour of the moth, and the chemical composition of the tree in relation to shade, were considered to be priority areas.

\section{Control}

Various control methods are practised by foresters and entomologists. They can be broadly categorized as chemical, biological and silvicultural.

\section{Chemical control}

Although attempts to control Hypsypila spp. by chemical means have bcen going on for about eighty years, and in some 21 countries, these methods have not been found to be effective or reliable. The difficulty is largely due to the inaccessibility of the larval stages (Wagner et al.. 1991). The development of resistance, and difficulties in applying 86 
insecticides, further complicate their use. Carbufuran was used, but was affecting birds, so had to be replaced by Carbosiphan. The latest insecticide to be recommended is Imidacloprid.

\section{Biological control}

Several biocontrol agents of Hypsipyla spp. have been reported. Roa \& Bennett (1969) reported more than 50 species of parasitoids and predators from India. Although the egg parasitoid Trichogramma sp. is well known, its use on Ilypsypila has not been successful. Of the several larval parasitoids, Tetrastichus phanerotoma and Cortesia spp. are known to give a parasitism rate of $70-80 \%$ for $H$. robusta. Attempts at classical biological control using parasitoids from India have failed in several countries (Clock, 1985). Inundative release of native parasitoids, however, has been recognized as an effective method. Of the commercially available pathogens. Bacillus thuringiensis has been found to be slow in action. Work is in progress on field-collected strains of Bacillovirus.

\section{Silvicultural control}

A wide range of different silvicultural approaches are practised in different countries. The incidence of attack has been found to be low when the trees are grown under a nurse crop. In natural forests. where there is regeneration from seed, low levels of infestation have been recorded compared with those in planted forests (Hidalgo-Salvatierra \& Palm. 1972). Research in Costa Rica has shown that there is considerable genetic variation in resistance to attack by shoot borers in many of the Meliaceac. The basis for resistance appears to be tolerance rather than preference or antibiosis.

\section{The situation in Sri Lanka:}

Five introduced species of Meliaccae are grown in Sri Lanka: Swietenia macrophylla is grown on 7300 hectares of the intermediate wet zone, Khaya senegalensisis in the dry zone, and Toona ciliata (formerly (edrela tuna) and (. mexicana in the tea estates. A significant point that came out of the discussions was the low level of damage caused by H. robusta in Sri Lanka; shade was considered to be an important contributing factor, together with a high incidence of parasitism by Cortesia spp. These factors and other features of the silvicultural system in Sri Lanka are to be examined in relation to shoot-borer damage.

\section{Setting research priorities}

At the end of the workshop, an attempl was made to identify the most important research areas. Six broad fields of study were recognized:

- taxonomy

- biology and ecology

- host resistance

- chemical control and pheromones

- biological control and pathogens

- silvicultural control 
A list was drawn up comprising 23 topics under these heads. The participants were asked to vote, on the basis of their cxperience, by assigning a high rank to three of the most impontant topics and a medium rank to those that are not so important. The results of the voting are given in Fig. 1. Standard resistance trials, mixed planting, and taxonomy ranked as the three areas needing most áttention.

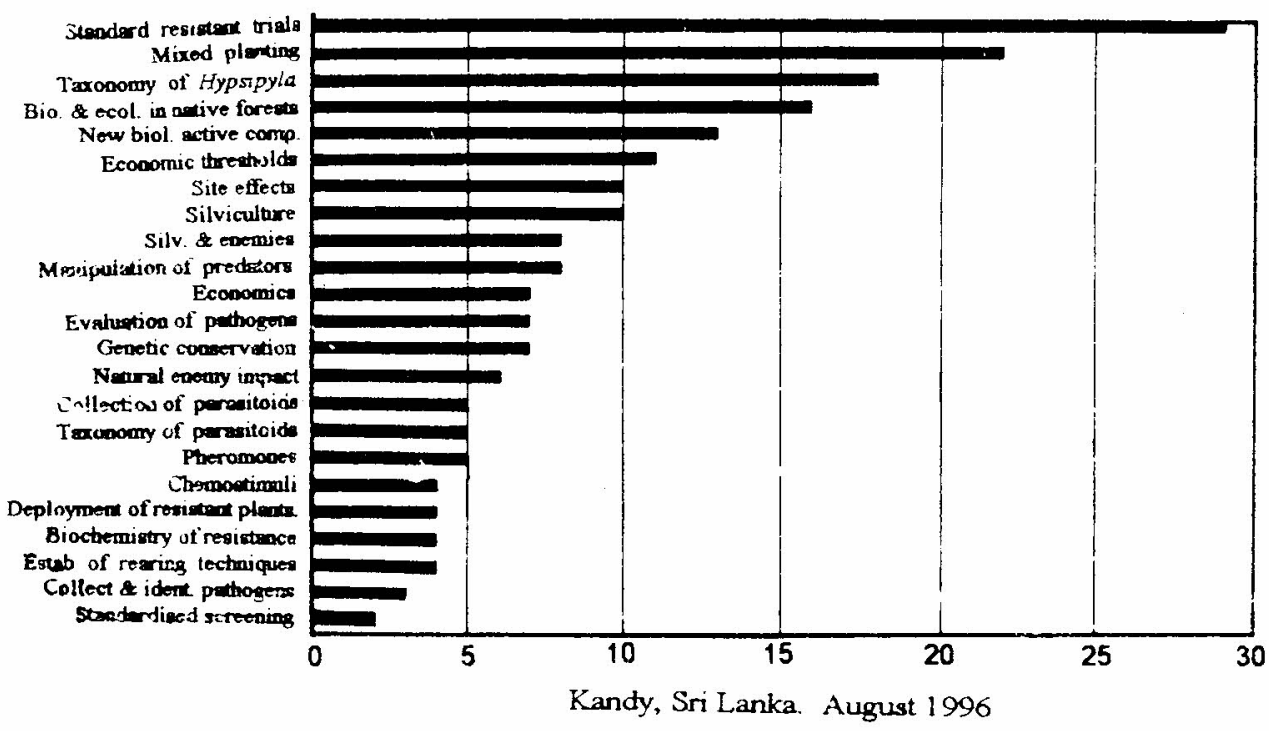

Figure 1: Results of Voting for Topics in Hypsipyla Research

\section{Conclusion}

Although significant progress has been made in research on the biology and control of Hysipyla spp., Meliaceae species are very much threatened in most of the countries in which they grow. Because of the very high timber value of these trees, and the limited area available for plantations. the need to protect the existing trees from Hysipyla shoot-borer attack is becoming increasingly important.

\section{References}

Beeson, C.F.C. (1941). The ecology and control of the forest insects of India and neighbouring countries. Dehra Dun, India. Vasant Press.

Clock. M.W. (Ed.) (1985). A review of the biological control of pests in the Caribbean and Bermuda, 1982. Technical Communication No. 9. Commonwealth Institute of Biological Control. 
Hidalgo-Salvatierra O, and Palm, J.D. (1972). Studies on the shoot borer Hypsipyla grandella Zeller (Lepidoptera: Pyralidae). XIV - Susceptibility of first instar larvae to Bacillus thuringiensis. Turrialba 22 (4) 467-468.

Rao, V.P. and Bennett, F.D. (1969). Possibilities of biological control of the meliaceous shoot borers Hypsipyla spp. (Lepidoptera: Phycitidae). (IBC. Technical Bulletin No.12, 61-81.

Wagner, M.R., Atuahena, S.K.N. and Cobbinah, J.R. (1991). Forest entomology in West Tropical Africa. Forest insects of Chana. Dordrecht, Netherlands. Kluwer Academic Publishers. 